\title{
Some considerations on the influence of economic liberalism in the May Revolution of 1810 in Buenos Aires, Argentina
}

\author{
Alfredo Félix BLANCO* \\ Universidad Nacional de Córdoba (Argentina) \\ alfredoblanco@eco.uncor.edu
}

Received: 11 April 2015

Accepted: 29 June 2015

\begin{abstract}
The revolutionary process of May 1810 in Buenos Aires, capital of the Viceroyalty of the Río de la Plata, occurred within the context of the French Revolution, the United States' struggle for independence and various changes in the European countries' economies. Liberal ideas played an essential role, and the opinions of Belgrano, Vieytes and Moreno, among others, are the key to understanding the economic perspectives of the revolutionary men. Late mercantilists, physiocrats and classical economists marked these men's economic thought. The purpose of this paper is to review these intellectual influences on the leaders of the May Revolution.
\end{abstract}

Keywords

Liberalism, classical economy, physiocrats, Manuel Belgrano, Mariano Moreno, Juan H. Vieytes

JEL classification: B10, B11, B12

Contents: 1. The creation of the viceroyalty of the Río de la Plata. 2. Economic ideas of the leaders of May. 3. Final considerations

\section{The creation of the viceroyalty of the Río de la Plata}

The revolutionary process of May 1810 in Buenos Aires (Argentina) and its emancipatory consequences have a multiplicity of causes. However, among these, the ideas of the founders of the political economy occupy an important position. These ideas, which would influence and be disseminated by Manuel Belgrano, Juan Hipólito Vieytes and Mariano Moreno among others, are the key to understanding the men of May's perspective on economy. ${ }^{1}$

The new political ideas of European intellectuals together with the appearance of works on the "new economic science" constitute the matrix for revolutionary thought. Late mercantilists, physiocrats and classical economists will leave their imprint in these men's ideas.

The change in intellectual paradigms, the crisis of the colonial economy, the political events in the Iberian Peninsula and the political action of the "men of May" would give birth to a new reality, with the tensions and contradictions it involved.

One of the main reasons for drawing up the Royal Decree of August 1, 1776 which created the Viceroyalty of the Río de la Plata was Spain's need to strengthen its control over these colonies. However, without intending to, it would ultimately contribute to creating the conditions which, together with other external factors, would end Spanish control of the colony.

The measures which accompanied the birth of the new viceroyalty not only freed Buenos Aires from the tutelage of Alto Peru, but also eliminated some obstacles that prevented its commercial expansion.

\footnotetext{
* The author thanks María Cayre, Marianela Restelli and Ignacio Villagra for their contributions to the paper. He is especially grateful to Marie Christine Duggan (Keene State College, New Hampshire, USA) for her comments, remarks and suggestions. He would also like to thank the comments and suggestions of the two anonymous referees.

${ }^{1}$ Juan José Castelli (1764 - 1812), deserves to be mentioned together with this "triumvirate", as well. He is remembered as the "speaker of the revolution", was Secretary of the Consulate and actively helped spread the ideas and events of the May Revolution. Wasserman (2011) has written a recent biography of Castelli which should be consulted.
} 
The creation of the viceroyalty was followed by a series of measures that contributed to the creation of an initially "shy" spirit of economic liberalism. One year after the creation of the viceroyalty, the Buenos Aires port was opened and this decision affected the interests of the traders from Peru and Chile and benefited the local and newly-formed commercial bourgeoisie. In 1778, King Charles III promulgated the Rules for the Free Trade of Spain and the Indies, which allowed reciprocal trade among the ports of Spain and those in "the Indies".

The new trade reality was accompanied by the creation of Customs (Royal Decree, June 25, 1778). The following years witnessed the birth of other "modernizing" institutions: the Commerce Consulate (1794), the Intendencias (1782) and the Real Audiencia (1783).

Regarding economic ideas, the birth of the "new science" which attempted to find answers that regarded economics in a systematic way meant the gradual decline of the mercantilist doctrines. Cantillon, Quesnay and the French physiocrats, Smith and the classical English school, and some Spanish authors ${ }^{2}$ announced the arrival of the economic liberalism.

In relation to the influence of the physiocracy, Lluch and Argemí (1994) ${ }^{3}$ pointed out that "the earliest relevant translations (into Spanish) were of an essay by Mirabeau (which later became part of L'Ami des hommes), translated by Serafin Trigueros, and of Quesnay's Maximes générales du gouvernement d'un royaume agricole, translated by Manuel Belgrano..." 4

In the Río de la Plata, the main actors of the May Revolution of 1810 would imagine the future from the perspective of economic liberalism. However, they were affected by inevitable contradictions consequent of the historical, political and social context of a region in which pre capitalist socio-economic structures would still be present during the following decades.

Towards 1808, the abdication of Ferdinand VII, together with the appearance of the Junta of Sevilla and the Supreme Central Junta years later, were all key factors that help explain what happened in 1810 in Buenos Aires.

A detailed analysis of the fall of the Spanish Empire in the Río de la Plata, and its transition to a new institutional context has been done by Adelman (1999). ${ }^{5}$

\section{Economic ideas of the leaders of May Manuel Belgrano ${ }^{6}$}

Belgrano is considered the first Argentinian economist in spite of having graduated as a lawyer from the University of Valladolid (1793). He was the first secretary of the Commerce Consulate of Buenos Aires (1794) and he not only knew about economy, philosophy and law but also translated the physiocrats' works into Spanish.

I confess that I did not apply myself so much to the career I had gone there to pursue, but rather to the study of living languages, political economy and public law, and that as soon as I had the fortune to find men devoted to the public good who shared their useful ideas with me, the desire to give as much as I could for the benefit of the public and to the acquisition of prestige for my works, aimed at favoring the homeland, took over me. ${ }^{7}$

Belgrano had multiple and varied ideological influences. His stay in Spain during the peak of the French Revolution and, as expressed by Ingenieros, the ideological roots of the South American revolution are "Rousseau's Social Contract as an expression of political liberalism [...]; Quesnay's General Maxims for the Economic Government as an expression of economic liberalism, discussed to justify the commercial interests of the colonies against the monopoly of the

\footnotetext{
${ }^{2}$ It is essential to highlight the great influence that the ideas of Valentín Tadeo de Foronda (1755-1821) and other Spanish intellectuals had over the "men of May". Cfr. Fernández López (2005).

${ }^{3}$ Lluch and Argemí. (1994, p. 616).

${ }^{4}$ The cited translations: Mirabeau (1764) and Quesnay [I794] (1984).

5 Adelman (1999), "Seccion I: The Age of Revolution, 1780's - 1820's"

${ }^{6}$ Manuel Belgrano (1770-1820), son of Domingo Belgrano y Peri and María J. González Casero, studied in the Real Colegio de San Carlos and continued his education in Salamanca and Valladolid.

${ }^{7}$ Belgrano (1966).
} 
metropolis [...]. Belgrano imported physiocratic ideas, translating Quesnay's economic maxims and glossing Campomanes". ${ }^{8}$ From Campomanes, Belgrano got his conviction that public instruction and education were essential means to foment industry and wealth. Campomanes promoted free trade and agriculture and, together with Jovellanos ${ }^{9}$, they constituted two very important influences on Belgrano's ideas. The Classical School, mainly Adam Smith, was very important too; the faith in the self-correction of the markets was being developed and economic liberalism was rising, gradually leaving scholastic and medieval worries behind. However, Belgrano was also influenced by less liberal authors such as Galiani ${ }^{10}$, Genovesi ${ }^{11}$, Filangieri ${ }^{12}$ and Feijóo $^{13}$. These influences were highly relevant when judging the more eclectic character of Belgrano's ideas. For example, Argemí d'Abadal points out that "the Argentine national hero Manuel Belgrano, one of the few Hispanic physiocrats, drew on Quesnay's ideas during the struggle for the independence of the Americas and proposed the reestablishment of the Inca monarchy as a political system for the continent". ${ }^{14}$ The idea of a "softened" monarchy is also expressed in the so-called "Carlotist Project" that viewed some men of May sympathetically. ${ }^{15}$

Belgrano's ideas on economy can be found in mainly three different places: (a) "physiocratic" translations from 1794 and 1796, (b) his memoirs from the Royal Consulate of Buenos Aires and (c) the articles that he published in the "Correo de Comercio" newspaper. ${ }^{16}$

The "translations" were carried out by Belgrano from French into Spanish. The first one (1794) was Quesnay's General Maxims for the Economical Government of an Agricultural Kingdom, and the second one (1796) was Principles of Political Economy. The latter had two parts: one of them included the principles of political economy and the other was a summary of the physiocratic ideas by the ruling Margrave of Baden.

Belgrano assumed his position as secretary of the Consulate of Buenos Aires in June 2, 1794, appointed by Charles IV. He wrote about this event:

When I finished my degree around 1793, the ideas of political economy were spreading in Spain with frenzy, and I think that this is why I was appointed as secretary of the Consulate of Buenos Aires, built in Minister Gardoqui's time, without me making any arrangements whatsoever for that to happen; and the secretary's official who was in charge of these issues even asked me to name individuals who had this knowledge so as to employ them in other institutions of the sort, which were being built in different business squares around America. ${ }^{17}$

\footnotetext{
${ }^{8}$ Ingenieros (1918) pp. 92 and 99. Cited in Fernández López and Orellana (1982, p. 426).

${ }^{9}$ Pedro Rodríguez Campomanes (1723-1802) (minister of Charles III) promoted economic reforms such as the liberalization of the grain trade. Gaspar de Jovellanos (1744-1811) wrote in 1794 A Report on the Dossier of the Agrarian Law. A detailed analysis of Jovellanos's economic thought, of the report, of his sources and of his influences, can be found in Llombart (1996 and 2010).

${ }^{10}$ Ferdinando Galiani (1728-1787) wrote Dialogues on the Commerce in Wheat (1770).

${ }^{11}$ Antonio Genovesi (1712-1769) wrote 'Lezioni di commercio o sia d'economia civile, one of the first Italian texts to address the topics of political economy in a systematic way.

${ }^{12}$ Gaetano Filangieri (1752-1788) is the author of Scienza della legislazione, written between 1780 and 1785. The work is considered an essential contribution regarding legal philosophy and it highlighted the tight interrelationship between de laws of politics and the laws of economy. Belgrano borrowed from Filangieri the notion of an economic structure integrated by agriculture, manufacturing and trade.

${ }^{13}$ Fray Benito Jerónimo Feijóo y Montenegro (1676-1764). His work is made up of nine volumes of Universal Critical Theatre and five volumes made up of his 163 Erudite and Peculiar Letters.

${ }^{14}$ Argemí d'Abadal (2012, p 147).

15 The name "Carlotist" derives from Princess Carlota, daughter of Carlos IV, sister of Fernando VII and wife of Dom João, Prince Regent of Portugal. The "Carlotist Project" encouraged the possibility of achieving independence through a smooth transition to an independent constitutional monarchy headed by Princess Carlota [cfr. McFarlane (2012)].

${ }^{16}$ On March 3, 1810 the first issue of "Correo de Comercio" was published.

${ }^{17}$ Belgrano (1966).
} 
For sixteen years (1794-1809), he was secretary of the Consulate ${ }^{18}$ and his ideas on economy can be appreciated in the "Memoirs" with which the body's sessions were annually opened. For Belgrano, the writing and reading of "Memoirs" were "a route for intellectual broadening and a contribution to the common good [...] he expressed all of his enthusiasm and his brilliance, this is the reason why the traditional opinion that the richest and most original of Belgrano's ideas can be found in his memoirs is completely justified". ${ }^{19}$

In the first memoir, read on June, 1796, Belgrano apologized for not having enough knowledge to describe the reality in the provinces as a consequence of his recent return from Spain. In this memoir, he seems to regard learned intellectuals rather than the members of the organism as the addressees of his words and he formulates general considerations about the State and "the general means for the development of Agriculture, as the fertile Mother that supplies all raw materials..." ${ }^{20}$ and adds: "Agriculture is the true destiny of man". ${ }^{21}$

The strong physiocratic influence can be appreciated in the title of the memoir itself: General Means to Foment Agriculture, Promote Industry, and Protect Trade, in an Agricultural Coun$t r y^{22}$. He argued that the cultivation of the land was essential for the arts and the exercise of industry, and that it further provided supplies for trade because: "It all depends on and results from the cultivation of the Lands; without it there are no raw materials for the Arts and, therefore, industry, which has no way to work, cannot provide materials for Trade to take place. Any other wealth that exists in an Agricultural State will be a precarious wealth..."23

One of the causes I find of the poor production of the lands and, consequently, of the lack of progress of the Producer, is not regarding Agriculture as an art that needs any study, consideration or rule. ${ }^{24}$

When Belgrano expressed these ideas, the viceroyalty was far from being the Agricultural State that he considered necessary and was closer to being the "early and rude state of society" mentioned by Smith in Chapter VI of The Wealth of Nations; Belgrano's concern was to achieve the development of that economy.

He established the existence of three conditions to improve the performance of agriculture: (i) that those who are in charge of the task of cultivating love agriculture and work with pleasure (ii) that they possess "power", that is, the essential resources with which to make improvements and (iii) that they possess farming-related knowledge because the lack of it generates few successful results. He encouraged the creation of a fund that would ease the producers' sowing and harvest of their products by stating:

I expect the idea to be adopted by acclamation so as to avoid the large monopolies that I have been informed that exist in this part of the Capital, run by those men who, lacking love for their equals altogether, only aspire to fulfill their particular interest, and who do not care at all if the most useful class of society, or the productive class of society as economists call it, live in misery and bareness which are a consequence of these procedures... ${ }^{25}$

Belgrano considered the role of education essential as a means to inspire people's abilities, avoid idleness and encourage work, and interpreted it as the engine of economy and the only

\footnotetext{
${ }^{18}$ His role during this period had some brief interruptions; in 1796 and 1800 he took a health related leave of absence and was replaced by Juan José Castelli. In 1806 he interrupted it as a consequence of the English invasion of Buenos Aires.

${ }^{19}$ Fernández López y Orellana (1984, p. 353)

${ }^{20}$ Belgrano (1996, p 12).

${ }^{21}$ Belgrano (1996, p. 12).

${ }^{22}$ The similarities with Quesnay's General Maxims of the Economical Government in an Agricultural Kingdom, which Belgrano had translated, are evident.

${ }^{23}$ Belgrano (1996, p. 13).

${ }^{24}$ Belgrano (1996, pp. 14-15).

${ }^{25}$ Belgrano (1996, p. 22).
} 
way to combat social exclusion. He manifested his concern about the existing social context by saying:

I have suffered the sight of a vast number of idle men in whom nothing but misery and bareness can be appreciated, without leaving this Capital; of a vast number of families who owe their survival to the Country's fertility, which is everywhere denoting the wealth it contains; this is abundance; and one can hardly find one single family which dedicates itself to a useful profession, masters an art or has a job that allows for some comfort in life. Those miserable shacks where one can see a multitude of creatures that reach puberty having been nothing but idle must be dealt with thoroughly. ${ }^{26}$

His view on manual and intellectual work as a central part of community life was socially revolutionary because, until that moment, high classes associated it with the role of slaves and servants exclusively. He stated that "to make men happy it is necessary to put them under the preciseness of work, which guards them from laziness and idleness, the origin of the dissolution of customs". ${ }^{27}$

With the aim of giving all people equal access to education, he suggested the establishment of free schools: "One of the main measures to be adopted [...] are free Schools where the unhappy could send their children without having to pay for a thing for their instruction; there, good rules of conduct could be provided and love for work could be inspired as, in a Country where this is absent, Trade worsens and misery takes its place...,28

The second Memoir of 1797 mainly explains the advantages of growing flax and hemp ${ }^{29}$. On top of making suggestions on how to produce them he proposed the granting of prices for those who used those crops and the giving away of seeds to encourage their exploitation. He encouraged the establishment of canvas and rope factories in Buenos Aires and Montevideo, regarding them as a benefit to the Nation: " textile factories, of either fine or raw fabric, of rope or any sort of rigging would grow: this growth would mean the employment of a huge number of hands that remain resourceless today". ${ }^{30}$

In this memoir, by the end, Belgrano shows again his physiocratic beliefs: "in this Province the real mine is the properly cultivated land which, as long as it is not looked after, will never make us rich, and, just like famous Quesnay states regarding every Agricultural State, it must be crowded with rich Producers". ${ }^{31}$

The following memoirs dealt with: "The Origin of Happiness in the Provinces is the Communion of Land-owners, Prices and Enlightenment in General" (1798), "The Establishment of Tanneries in the Viceroyalty" (1802) and "The Importance of the Study of Mathematics" (1805).

The newspaper "Correo de Comercio" was used by Belgrano to disseminate his ideas. The topics were diverse but the pieces on trade, education, economy, politics, and geography. He had very clear theoretical economic concepts. He expressed advanced reasoning related to pricing, involving both supply and demand and combining objective and subjective elements to determine it.

The absence of a debate about value should not be considered a limitation of his theoretical knowledge. Physiocratic views were shaped by the dominant characteristics of the French economy during the mid-eighteenth century, which made them reason in terms of physical productivity to define produit net without resorting to an exchange value theory. In a similar manner, Belgrano, with a pre-capitalist reality in front of him, could not (and maybe did not have to)

\footnotetext{
${ }^{26}$ Belgrano (1996, pp. 25-26).

${ }^{27}$ Belgrano (1996, p. 26).

${ }^{28}$ Belgrano (1996, p. 26).

29 The complete title of the memoir is "Profits for this Province, and the Peninsula, as a Result of Growing Flax and Hemp; How to Do it; the Most Convenient Land for it; Ways to Harvest these Two Crops; and, Finally, the Ways to Make our Producers Work in this Branch of Agriculture with Determination"

${ }^{30}$ Belgrano (1996, 36).

${ }^{31}$ Belgrano (1996, p. 46).
} 
think in terms of the production of exchange values. By that time, English classics did have to do so, and they developed a labour theory of value to understand the new economic organization and the social relationships derived from it.

Belgrano thought the sources of wealth were to be found in agriculture, trade and industry and at the beginning of his first piece in "Correo de Comercio" he stated so, forcefully:

Producers, you who provide society with your effort and sweat that allow for society's subsistence, with the gift of products and the raw materials required by the State! Artists, you who know how to settle nature's productions by giving them a new shape for a different use from the expected one, and add new value with which to enrich the State and contribute to its prosperity! Traders, you who drive change both internally and externally with your activity and through whose means agriculture and industry are encouraged; the State receives the utilities with which it meets its needs and emergencies! ${ }^{32}$

The concept of interdependency of the different sectors of economy, was also present: "the mutual dependency of agriculture and trade is such that one cannot flourish without the other" and, talking about the foundation of trade he states that "agriculture and industry are its essence; they are joined in such a way that if one weighs more than the other it destroys itself. The products of the land with no industry will have no value, if agriculture is neglected the channels for trade are obstructed". ${ }^{34}$

In spite of not having developed a theory of value, he defined productivity in a more broad way than physiocrats because he did not link it to an exclusively physical event but rather associated it with economic values; he did not limit the production of economic surplus (the physiocratic produit net) to agriculture.

On monetary matters, he expressly recognizes the functions of money as a unit of measure and as a means of change, approaching the idea of "money veil", typical of classical thought. He offered a basic perception of the Quantity Theory of Money by saying that the extraordinary rise of all prices is related to "that infallible principle that states that the value of things arises from the total amount of cash in circulation...,"35

He suggested the elimination of the existing barriers to trade and advocated for free trade, but he allowed for restrictions when the import of goods hindered the consumption of national goods or hindered its fabrication.

\section{Juan Hipólito Vieytes ${ }^{36}$}

Vieytes is remembered mainly due to his participation and political commitment with the revolutionary movement of May, $1810^{37}$. His job as the head of the newspaper entitled "Semanario de Agricultura, Industria y Comercio" 38 turned him into the first "Criollo journalist".

However, it is important to highlight his importance as an economist, for which he is often not appropriately appreciated. He has been treated with certain intellectual contempt by Robert S. Smith ${ }^{39}$ and Luis Roque Gondra ${ }^{40}$, but, as Carlos Rodríguez Braun pointed out, "although Vieytes was no innovative theoretician nor a scholarly prepared thinker, he was an early and

\footnotetext{
${ }^{32}$ Gagliano (2011, p. 71).

${ }^{33}$ Varo y Coria (1998, p. 7).

${ }^{34}$ Varo y Coria (1998, p. 7).

${ }^{35}$ Varo y Coria (1998, p. 9).

${ }^{36}$ Juan Hipólito Vieytes (1762-1815), son of Juan Vieytes and Petrona Mora Fernández de Agüero. After the death of Mariano Moreno, to whom he was politically really close, Vieytes replaced him as Secretary of the Primera Junta (or "First Assembly").

${ }^{37}$ Vieytes set up a business (a soap factory) together with his friend Nicolás Rodríguez Peña, the premises of which were frequently used as clandestine meeting place for the revolutionary men.

${ }^{38}$ Vieytes edited "Semanario" between 1802 and 1807. He also wrote for "Correo de Comercio de Buenos Aires", published between 1810 and 1811.

${ }^{39}$ Cfr. Smith (1957).

${ }^{40}$ Cfr. Gondra (1927).
} 
able divulgator of Smithian economics and deserves to be counted among the Spanish and Spanish-American economists of his day". ${ }^{41}$

Vieytes was a great admirer of and expert on Adam Smith and his propagandists. He refers to the Scottish philosopher as "the sublime economist" and draws his main concepts from The Wealth of Nations. ${ }^{42}$

Just like in Belgrano's case, another important influence was constituted by the works of the physiocrats, which suggested the need to obtain maximum profit from the land and advocated for the development of farming activities. He considered agriculture the only noble and honest activity that would allow for the production of true wealth and he even believed it to be a patriotic activity.

As it has already been stated, stock breeding was more developed than agriculture, but Vieytes held the need to expand the latter having the long-term growth of a capitalist economy in mind based on this activity's productivity growth. Moreover, during this stage, stock breeding seemed less compatible with liberal ideas because it motivated the monopoly of the use of the lands by those who possessed them.

Vieytes believed that the development of farming was to take place soon in the Río de la Plata because it would be unavoidable after a correct delimitation of property rights, education and trade. In his own words: "For our fields to succeed, property must be ensured so that no one feels restless about it; the ease with which it is upset is the cause of the slow growth which can be seen in our beautiful fields". 43

The desire to possess is born together with man; those who do not own a property are those who do not have enough means to get one; let us ease the way towards satisfying this wish and we will have settlers to spare. ${ }^{44}$

He was equally clear with his opinions about free trade and he vehemently rejected monopoly and the existence of barriers to international trade.

His view of the economic "system" was presented in the articles published by the "Semanario de Agricultura, Industria y Comercio". In fact, the title of the newspaper itself gives us a perspective of his concerns: the development and interrelation of agriculture, industry and trade. Vieytes expects economy to be a system of interrelated parts: "Producers: No Nation can prosper without the development of industry; its extension is enormous, its products countless and its usefulness is beyond words. Everything that is produced by the three kingdoms of nature can be subjected to industry, and all of what industry embraces is useful for men". ${ }^{45}$

Vieytes highlighted the importance of personal interest as an engine of human conduct, as well as productive work, the division of labour, and trade, which allows for the creation and distribution of wealth. With a statement which could have been included in Adam Smith's Theory of Moral Sentiments, he expressed his belief that personal interest is the main motivation of human conduct: "For man to get rid of inaction and laziness, no other path is known but that of using interest as bait ". 46

He suggested that one of the prerequisites for economic growth is availability of labour force and, therefore, he advocated for measures to populate the territory.

He was also concerned about the importance of productivity and, referring to the incorporation of innovative technologies, he wrote for "Semanario" about the new tanning methods in England: "we can make in one day what used to take months before, saving time, efforts and handling costs". ${ }^{47}$

\footnotetext{
${ }^{41}$ Rodríguez Braun (1997, p. 444).

${ }^{42}$ The first Spanish edition of Adam Smith's work was published in Madrid in 1794, and Vieytes owned several editions of The Wealth of Nations (cfr. Smith, 1957).

${ }^{43}$ Cited in Rojas (2010, p. 204-205).

${ }^{44}$ Cited in Rojas (2010, p. 207).

45 “Semanario" N ${ }^{\circ}$ 2. Cited by Rojas (2010, p. 171),

${ }^{46}$ Cited in Rojas (2010, p. 132).

${ }^{47}$ Cited in Rojas (2010, p. 172).
} 
Just like in Belgrano's case, Foronda was an important source of inspiration for him, and his influence can be clearly perceived in a couple of letters published in "Correo de Comercio", both attributed to Vieytes. One of them deals with trade unions, while the other deals with "the unfair tax on food products". Moreover, in "Correo de Comercio", Vieytes recommended reading texts about education, philosophy and logic which had been translated into Spanish by Foronda.

Franklin was another author studied by Vieytes, and he reproduced in "Semanario" the articles by the American hero which had been published in Europe. ${ }^{48}$

Crumpe was also a great influence on Vieytes' economic ideas ${ }^{49}$. Between February and June, 1805, Vieytes published translations of several parts of Crumpe's work. ${ }^{50}$

Physiocracy had a decisive influence on Vieytes' ideas even though, as it has already been stated, Belgrano was the main scholar and purveyor of Quesnay and his disciple's ideas in the Río de la Plata. ${ }^{51}$

Jovellanos, who also advocated for the encouragement of agriculture, mercantilist Uztáriz ${ }^{52}$, and the Italian Galiani also contributed to the formation of Vieytes' economic ideas.

To summarize these influences it is worth noting that Vieytes was inspired by the ideas of the thinkers who have been mentioned and the liberal spirit of the time in spite of the relative "backwardness" of the Spanish territories in the Río de la Plata. He stated: "all wise Nations have agreed on granting indefinite freedom to their own businessmen". ${ }^{53}$

His belief that the interdependency of the countries is only natural and one of the bases of free trade was summarized in "Semanario" when he wrote that

The world is no other thing but a large population shared out in many headquarters even if there are seas, vast deserts and terrible, almost inaccessible mountain ranges between them; industry has eased the difficulties which impeded social contact, and there is no longer any region which is unaware of the existence of the others, with which it holds an uninterrupted wisdom involving active and passive trade. ${ }^{54}$

In the society contemplated by the "men of May", respect for property was essential: "For our lands to succeed property must be ensured so that no one feels restless about it [...]. He who lives in a country ruled by peace and respect for property shall be happy: without these, it cannot be enjoyed, farming involves fear, the products are collected with anxiety, and work is done with no hope of improving" ${ }^{55}$ That respect for property rights, a basic prerequisite for the construction of a modern capitalist society, would be encouragement enough for men to produce more.

\section{Mariano Moreno $^{56}$}

\footnotetext{
${ }^{48}$ In issue number 55 of "Semanario", Vieytes published Franklin's article "Easy Way to Pay Taxes" (cfr. Rojas, 2010 p. 209).

49 Samuel Crumpe (1766-1796) was the author of An Essay on the Best Means of Providing Employment for the People. It has been suggested that Vieytes was more interested in Crumpe's works than in Adam Smith's himself because the style of the former was closer to journalism (cfr. Rodríguez Braun, 1997).

${ }^{50}$ For example the "Memoir" entitled "Economic Freedom, Low and Fair Taxes and Property Security are Necessary for the Development of Economy. Taxes should not Impede or Stop Trade.", published in the issue of March 27, 1805 (Vieytes, 1802-1807, vol. 3 pp. 235-240).

${ }^{51}$ Physiocratic influences made Vieytes reflect upon farming topics. In these matters he was influenced by Jean-Baptiste François Rozier (1734-1793), author of the "Cours complet d'agriculture théorique..."

${ }^{52}$ Gerónimo de Ustáriz $(1670$-1732) his main work was The Theory and Practice of Commerce and Maritime Affairs (1724).

${ }^{53}$ Rojas (2010, p. 182).

${ }^{54}$ Rojas (2010, p. 186).

${ }^{55}$ Rojas (2010, p. 204-205).

${ }^{56}$ Mariano Moreno (177 -1811) was born in Buenos Aires. His parents were Manuel Moreno y Argumosa and Ana María Valle. Moreno excelled as a student and could enter a prestigious Latin American university: la Universidad Mayor, Real y Pontificia de Chuquisaca, in Upper Peru (currently Sucre, the constitutional capital of the Plurinational State of Bolivia).
} 
Moreno was one of the most distinguished men of the May Revolution of 1810. Owner of a powerful intelligence, endless energy and complete commitment to the cause, he was Secretary of War and Government of the Primera Junta. ${ }^{57}$ In Chuquisaca, he had access to the library of his tutor, Matías Terrazas, which was essential for him to get acquainted with the works of the great writers of the time. Moreno educated himself by reading Montesquieu, Daguesseau, Raynal, Mably, Locke, Filangieri, Rousseau and Voltaire among many other authors who influenced his ideas.

(Moreno) did not face life superficially. While his protector, the priest, spent his life in social gatherings and took advantage of the knowledge he had acquired during his youth, Mariano isolated himself in the library and read with the greed of those who look for answers and orientation in the books with which to combat existence... ${ }^{58}$

Rousseau's influence was very important, and his admiration for the Genevan thinker could be seen in the preface of the translation of the Social Contract: "This immortal man, who gained the admiration of those of his century and will amaze people of all ages, was, perhaps, the first to shed light on the rights of the peoples...",59

These works filled him with revolutionary ideas, although inquisitorial practices, which were still in use, forced him to conceal his convictions. It must be taken into account that those who did not agree with the way of thinking of the colonial authority and the Real Audiencia de Charcas ran the risk of being severely sanctioned. Monteagudo ${ }^{60}$ said about this:

Who would dare look at the chains with contempt at that time without turning into the prisoner of an enormous assault against the authority of ignorance? [...] If, tragically, someone refused to idolize despotism and complained about the oppression, shortly after the hand of the executioner would present him as a trophy on the scaffold and he would die shamefully accused of treason to the king. ${ }^{61}$

"The Representation of the Landowners" (1809), the "Revolutionary Operations Plan" (1810), "On the Parliament which has just been Formed and the Constitution of the State" (1810), the preface of the translation of Rousseau's 'Social Contract"' (1810) and his document on the "President's Honors Suppression" (1811) are his most famous works.

"The Representation of the Landowners" is an allegation with strongly liberal economic and political content, which supports free trade with Great Britain and deals with the need to strengthen the State. Moreno senses the decline of the institutions of the viceroyalty and the need to generate a larger income, as well as the growing importance of smuggling of English goods which escaped the colonial monopoly restrictions. Free trade is a necessity, an unavoidable decision which does not require any proof.

There are truths which are so evident that trying to prove them so would be an insult to reason. The proposal that open import of stock which it does not produce or have, and the export of products which abound and are spoilt due to a lack of an outlet is convenient for the country is an example of this". ${ }^{62}$ Consult the economists who wrote with knowledge about the origin and progress of political states, and all calculations will be seen to be derived from that principle... ${ }^{63}$

\footnotetext{
${ }^{57}$ Strictly speaking, the "Junta" of which Moreno was a part was the second one, as the Cabildo had already set a junta which lasted only one day. Its limited duration explains why the junta joined by Moreno is always referred to as Primera ("first") Junta.

${ }^{58}$ Puiggrós (2012, p. 14-15).

${ }^{59}$ Moreno [1810 b (1915)].

${ }^{60}$ Bernardo de Monteagudo (1789-1825) was one of the leaders of the Revolution of Chuquisaca from May 25, 1809, and he had relations with the most radical groups of the May Revolution of 1810.

${ }^{61}$ Puiggrós (2012). Page 20.

${ }^{62}$ Moreno [1809 (1915)].

${ }^{63}$ Moreno [1809 (1915)].
} 
He dismissed the (mercantilist) concern that free trade could cause losses for the nation and he was categorical when defining wealth following the ideas of classical economists, with the concepts of market price, supply and demand in mind: "Silver is not wealth, as it is compatible with the evils and difficulties of extreme misery; it is no more than a conventionalized sign used to represent all commercial goods...". ${ }^{64}$

In "Revolutionary Operations Plan", severe political judgments can be found which show his "Jacobin" side: "The foundations of a new republic have never been consolidated with anything but rigor and punishment mixed with the blood shed by all those members who tried to stop its development...." ${ }^{\text {B }}$ But, regarding economic matters, this document contains expressions which distance him from a strict economic liberalism:

Art. $6^{\circ}$ Regarding the judgments which must be adopted to increase public funds aimed at covering the expenses of war and other undertakings after Peru and the rest of the viceroyalty succumb", and he adds: "... all miners should be forced to get rid of all their tools by selling them to the State for a fair price, ... sugar mills should be created together with all necessary offices, such as laboratories, mints and any other building depending on the case... ${ }^{66}$

Because only one year separated "The Representation of the Landowners" and the "Revolutionary Operations Plan", Moreno's presumed change of mind created controversies among the historians. The argument reached a point in which those who saw Moreno as a liberal started to doubt the authorship of the "Revolutionary Operations Plan". ${ }^{67}$ But no one can deny the influence that liberal thinkers had on Moreno, and it is also necessary to understand that his participation in the events of May and the government, once convinced about the crisis and dissolution of the old Spanish empire, forced him to reflect upon the new-born State.

That "new" State had to be an active leading figure in economic activities which could not be undertaken by a strong bourgeoisie because there was no such thing in the Río de la Plata at the time. So, Moreno was more pragmatic than theoretical. If the need for that pragmatism is understood, a clear proximity can be perceived between "The Representation of the Landowners" and "Revolutionary Operations Plan".

\section{Final considerations}

The revolutionary process of May 1810 has a multiplicity of causes. The French Revolution, the independence of the United States, the changes in the economies of the European countries since mid-eighteenth century, the changes in their social and economic relations and their later evolution, all make up the context in which the events of this Spanish colonial territory take place. In that historical context, the growing influence of liberal ideas, both in the political and economic fields, have a decisive role in the revolutionary events. The new political ideas of the European intellectuals, together with the publication of works on the "new science" of economics constitute the matrix of revolutionary thought.

The opinions of Belgrano, Vieytes and Moreno, among others, are the key to understand the perspective that the men of May had on economy. Late mercantilists, Physiocrats and classical economists left a mark in these men's ideas. The comments and citations about these three leaders of the May Revolution of 1810 are evidence of the dominant presence of the ideas of economic and political liberalism.

However, the relative economic "backwardness" of the Spanish metropolis, its political crisis and the consequences it had for the viceroyalty are both a catalyst for the revolutionary process, and a limit which can be seen in the arguments and debates among the leaders of that historical period. The change of intellectual paradigms, the crisis of colonial economy, the gradual emergence of the institutions of modern capitalism and the political events which took place in the

\footnotetext{
${ }^{64}$ Moreno [1809] (1915).

${ }^{65}$ Moreno [1810 c] (1915)

${ }^{66}$ Moreno [1810 c] (1915)

${ }^{67}$ The document was spread by Piñero [1896] (1938). Paul Groussac and Ricardo Levene, among others, stated that the author was not Moreno; but this hypothesis has lost support, Cfr. Puiggrós (2012).
} 
Iberian Peninsula, together with the actions of the "men of May", will give birth to a new reality, together with its tensions and contradictions. The convictions (some of them radical, others eclectic) of those who decisively contributed to the end of the Spanish colonial system in South America took time to consolidate. The ideas of freedom, property and free trade, which vigorously took over after the arrival of European capitalism, were not consolidated with the May Revolution. The issue of Argentina's national unity will remain unresolved for fifty years after that $^{68}$.

Finally, the leaders of the national emancipation of Argentina will reach the end of their lives with discouraging feelings. They could have easily ended their lives with the comment attributed to Juan José Castelli, stated in his deathbed: "If you see the future, tell him not to come".

\section{Bibliography}

Adelman, Jeremy. 1999. Republic of Capital: Buenos Aires and the Legal Transformation of the Atlantic World. Stanford, Stanford University Press.

Argemí d'Abadal, Lluís. 2012. The Physiocrats. In Handbook of the History of Economic Thought. Jürgen Georg Backhaus ed. New York, Springer Science + Business Media. See http://digamo.free.fr/backhaus122.pdf

Belgrano, Manuel. [1954]. Escritos económicos. Buenos Aires, Raigal.

- [1966]. Autobiografía y otras páginas. Buenos Aires, Eudeba. See http://manuelbelgrano.gov.ar/seccion-belgrano/primer-parte

- [1996]. Memorias. Buenos Aires, Biblioteca Pagina 12. Compilación de Manuel Fernández López.

Fernández López, Manuel and Orellana, Danaide. 1982. Manuel Belgrano y las Máximas de Quesnay. Anales de la Asociación Argentina de Economía Política, XVII Reunión Anual, Volumen (1). See. http://www.aaep.org.ar/anales/works/works1982/fernandez delvalle.pdf

Fernández López, Manuel. 2005. Cartas de Foronda: su influencia en el pensamiento económico argentino. Anales de la Asociación Argentina de Economía Política, XLI Reunión Anual, Volumen (1). See http://www.aaep.org.ar/anales/works/works2005/fernandezlopez.pdf

Foronda, Valentín de [1994] 1821. Cartas sobre los asuntos más exquisitos de la Economía Política y sobre las Leyes criminales. Pamplona, Vitoria (Departamento de Economía y Hacienda del Gobierno Vasco - Colección Clásicos del Pensamiento Económico Vasco. Tomo I).

Gagliano, Rafael. 2011. Escritos sobre educación. Selección de textos / Manuel Belgrano. Presentación de Rafael Gagliano. $1^{\text {st }}$ ed. La Plata, UNIPE: Editorial Universitaria. See http://unipe.edu.ar/wp-content/uploads/2011/11/Escritos-sobre-Educacion-de-ManuelBelgrano.pdf

Genovesi, Antonio. 1769. Lezioni di commercio o sia d'economia civile. Bassano, Remondini http://books.google.com.ar/books/about/Lezioni_di_commercio_o_sia_d_economia_ci.html?i $\mathrm{d}=$ W709AAAAcAAJ\&redir esc $=\mathrm{y}$

Gondra, Luis Roque. 1927. Las Ideas Económicas de Belgrano. Buenos Aires, Imprenta de la Universidad.

Ingenieros, J. [1961] 1918. La evolución de las ideas argentinas. Buenos Aires. Reimpresión.

Llombart, Vicent. 1996. El Informe de ley agraria y su autor en la historia del pensamiento económico. In: García Sanz, Ángel y Sanz Fernández, Jesús (coord.), Reformas y políticas agrarias en la historia de España. (De la Ilustración al primer franquismo), Madrid, Ministerio de Agricultura, Pesca y Alimentación, pp. 105-159. See http://www.magrama.gob.es/ministerio/pags/Biblioteca/fondo/pdf/17080_6.pdf

\footnotetext{
${ }^{68}$ In the four decades that followed the May Revolution, a civil war between "federalists" and "unitarians" broke out and impeded almost completely the existence of a central government. This period ended with the Battle of Caseros (February 3, 1852), in which Urquiza defeated Rosas. The following year, the Constitution was enacted, but the country remained divided; Buenos Aires on the one hand and on the other the Confederation (the other provinces). The division lasted until 1861, when Bartolomé Mitre defeated Urquiza (Battle of Pavón) and unified the country.
} 
- 2010. Una aproximación histórica y analítica al pensamiento económico de Jovellanos. Asociación Española de Historia Económica. DT-AEHE No1012. See http://www.aehe.net/2010/11/dt-aehe-1012.pdf

Lluch, Ernest and Argemí, Lluís. 1994. Physiocracy in Spain. History of Political Economy 26 (4), pp. 613-627. Duke University Press. See http://diposit.ub.edu/dspace/bitstream/2445/9172/1/137068.pdf

McFarlane, Anthony. 2012. Princess Carlota Joaquina and the Monarchist Alternative in Spanish American Independence. Liberalism in the Americas Collection. London, Institute of Latin American Studies, University of London. See http://sasspace.sas.ac.uk/4280/1/LIA\%2C Monarchist_Alternative\%2C McFarlane\%2C 10.02.12.pdf

Mirabeau, Victor Riquetti, marquis de. 1764. Disertación sobre el cultivo de trigos, que la Academia de Agricultura de la ciudad de Berna, en Suiza, premió en el año 1760. Translated by Serafino Trigueros. Madrid, Joachin Ibarra.

Moreno, Mariano. [1915] 1809. La representación de los hacendados. In Doctrina democrática. Ricardo Rojas ed. Buenos Aires, Librería La Facultad. See http://www.biblioteca.clarin.com/pbda/ensayo/moreno_escritos/hacendados.html

- [1915] 1810a. Sobre las miras del Congreso que acaba de convocarse, y Constitución del Estado. In Doctrina democrática. Ricardo Rojas ed. Buenos Aires, Librería La Facultad. See http://www.biblioteca.clarin.com/pbda/ensayo/moreno_escritos/congreso.html

- [1915] 1810b. Plan revolucionario de operaciones. In Doctrina democrática. Ricardo Rojas ed. Buenos Aires, Librería La Facultad. See http://www.biblioteca.clarin.com/pbda/ensayo/moreno escritos/b-605101.html

- [1915] 1810c. Prólogo a la traducción del Contrato Social. In Doctrina democrática. Ricardo Rojas ed. Buenos Aires, Librería La Facultad. See http://www.biblioteca.clarin.com/pbda/ensayo/moreno_escritos/contratosocial.html

- [1915] 1810d. Supresión de los honores del Presidente. In Doctrina democrática. Ricardo Rojas ed. Buenos Aires, Librería La Facultad. See http://www.biblioteca.clarin.com/pbda/ensayo/moreno escritos/supresion.html

Piñero, Norberto. [1938] 1896. Los escritos de Mariano Moreno. Buenos Aires, Librería y Casa Editora de Jesús Menéndez.

Puiggrós, Rodolfo. 2012. La época de Mariano Moreno. Buenos Aires. Edit. Punto Crítico. $3^{\mathrm{a}}$ ed.

Quesnay, François. [1984] I794. Máximas generales del gobierno de un reino agricultor. Translated by Manuel Belgrano. Madrid, Instituto de Cooperación Iberoamericana.

Rodriguez Braun, Carlos. 1997. Early Smithian economics in the Spanish empire: J. H. Vieytes and colonial policy. The European Journal of the History of Economic Thought, 4 (3), pp. 444-454.

Rojas, Ricardo. 2010a. El pensamiento económico de Juan Hipólito Vieytes. $1^{\text {st }}$ ed. Buenos Aires, Fundación San Antonio. See http://www.hacer.org/pdf/Rojas05.pdf

- 2010b. Propiedad, productividad y comercio: el Pensamiento económico de Juan Hipólito Vieytes. Revista de Instituciones, Ideas y Mercados, 53.pp. 203-238. See http://www.eseade.edu.ar/files/riim/RIIM 53/53 7 rojas.pdf

Rozier, Jean-Baptiste François. 1781- 1800. Cours complet d'agriculture théorique, pratique, économique, et de médicine rurale et vétérinaire; suivi d'une Méthode pour étudier l'agriculture par principes: ou Dictionnaire universel d'agriculture. Paris, Imprimerie Marchant et Claude Simon.

Smith, Robert Sidney. 1957. The Wealth of Nations in Spain and Hispanic America, 1780-1830. Journal of Political Economy, 65 (2), April. pp. 104-125

Varo, Roberto. and Coria Luis.. 1998. Conceptos económicos de los escritos de Manuel Belgrano. See http://portal.eco.unc.edu.ar/files/Biblioteca/conceconmb.pdf

Vieytes, Juan Hipólito. 1802-1807. Semanario de Agricultura Industria y Comercio (5 Tomos). Facsímil. Fundación Hernandarias. See http://hernandarias.edu.ar/seadh/?p=356\#7p

Wasserman, Fabio. 2011. Juan José Castelli. De súbdito de la corona a líder revolucionario. Buenos Aires, Edhasa. 